\title{
VEGF and Notch in Tip and Stalk Cell Selection
}

\author{
Raquel Blanco and Holger Gerhardt \\ Vascular Biology Laboratory, London Research Institute, Lincoln's Inn Fields Laboratories, London \\ WC2A 3LY, United Kingdom \\ Correspondence: Holger.Gerhardt@cancer.org.uk
}

Sprouting angiogenesis is a dynamic process in which endothelial cells collectively migrate, shape new lumenized tubes, make new connections, and remodel the nascent network into a hierarchically branched and functionally perfused vascular bed. Endothelial cells in the nascent sprout adopt two distinct cellular phenotypes—-known as tip and stalk cells — with specialized functions and gene expression patterns. VEGF and Notch signaling engage in an intricate cross talk to balance tip and stalk cell formation and to regulate directed tip cell migration and stalk cell proliferation. In this article, we summarize the current knowledge and implications of the tip/stalk cell concepts and the quantitative and dynamic integration of VEGF and Notch signaling in tip and stalk cell selection.

\section{ANGIOGENESIS: TIP AND STALK PHENOTYPES}

\begin{abstract}
ngiogenesis is the process of expanding Aexisting blood vessel networks mainly by sprouting new branches that connect and subsequently remodel into a functional vascular circuit. The process is generally initiated in the context of tissue growth, either during development or cancer, during inflammation and wound healing, or during increasing physiological metabolic tissue demands in physical training. Once the new vessels establish nutrient and oxygen supplies that meet the metabolic tissue demand, the vessels will become quiescent (Risau 1997).

A key trigger of angiogenesis is local tissue hypoxia, which activates local cellular production of proangiogenic growth factors such as vascular endothelial growth factor (VEGF)
\end{abstract}

and cytokines. Previously quiescent endothelial cells of vessels reached by the proangiogenic VEGF signal become (re)activated to initiate the angiogenic program. At the cellular level, the initiation of sprouting angiogenesis requires cells to break out of the vessel wall, degrade basement membrane, change their cell shape, proliferate, and collectively invade the surrounding tissue while remaining connected with the vessel network (Fig. 1).

Over the past decade, it has become clear that individual endothelial cells (ECs) adopt specialized phenotypes and functions to coordinate behavior in what might best be described as teamwork (Phng and Gerhardt 2009).

The endothelial cells spearheading the vascular sprouts are known as the endothelial tip cells (Gerhardt et al. 2003). Tip cells are characterized by their position, their long and dynamic filopodia, and their migratory

Editors: Michael Klagsbrun and Patricia D'Amore

Additional Perspectives on Angiogenesis available at www.perspectivesinmedicine.org

Copyright (C) 2013 Cold Spring Harbor Laboratory Press; all rights reserved; doi: 10.1101/cshperspect.a006569

Cite this article as Cold Spring Harb Perspect Med 2013;3:a006569 
A

Quiescent endothelium stimulated by VEGF-A EC activation and ECM degradation

$\because \because \cdots \cdots$

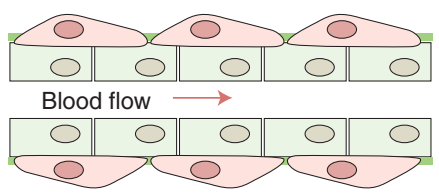

D

Stalk elongation

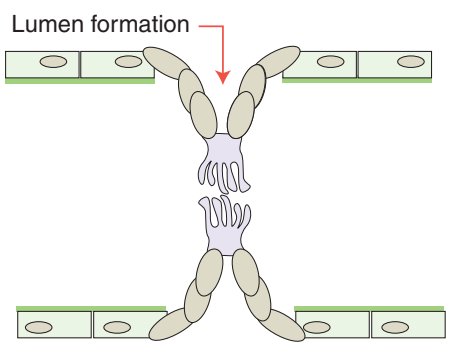

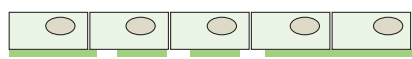

E

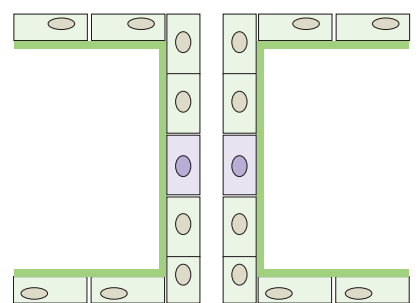

C

Tip and stalk cell selection

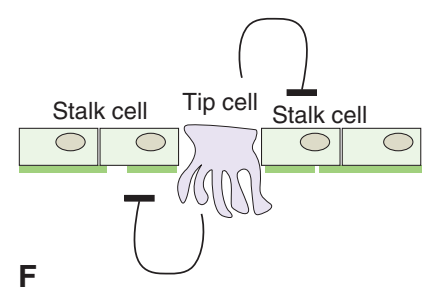

Maturation and stabilization
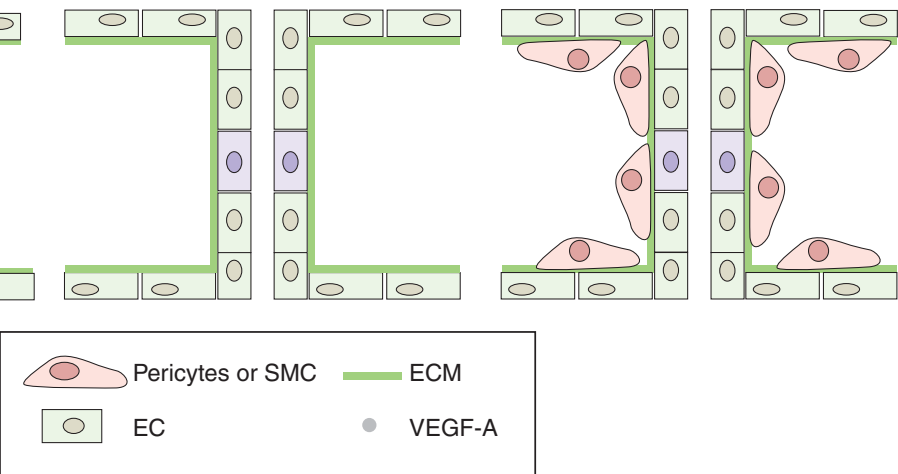

Figure 1. Schematic model of sprout initiation, vessel branching, and maturation. Angiogenesis is activated in response to local tissue hypoxia. The hypoxic tissue releases endothelial growth factor, that is, VEGF-A, which (re)activates the quiescent endothelial cells (ECs). (A) At the cellular level, the angiogenic initiation requires the degradation of the extra cellular matrix $(\mathrm{ECM})(B)$ as well as the specification of the (re)activated ECs into tip and stalk cells $(C)$. ECs proliferate and collectively invade the hypoxic tissue while they remain connected to the original vascular network. $(D)$ In the nascent sprout, the tip cells, characterized by their migratory behavior and dynamic filopodia, lead the sprout toward the VEGF-A source, whereas the stalk cells proliferate to support sprout elongation. The tip cells connect the new sprouts into a functional vessel loop. $(E)$ The new connection between different sprouts occurs through tip cell fusion (anastomosis). Formation of the vascular lumen initiates blood flow, increases tissue oxygenation, and, in turn, reduces the release of endothelial growth factors, supporting the establishment of quiescence. $(F)$ Vessel maturation and stabilization proceed with the recruitment of mural cells (pericytes) and the deposition of ECM.

behavior (Gerhardt et al. 2003). Analogous to an axonal growth cone, the tip cells integrate attractive and repulsive directional cues presented by the environment and thereby define the route in which the new sprout grows (Gerhardt et al. 2003). Moreover, the tip cells are required to create new connections between different sprouts to generate an interconnected and functional vascular network (Fig. 1) (Isogai et al. 2003).

Following the tip cells are the endothelial stalk cells, which produce fewer filopodia, are highly proliferative, establish adherent and tight junctions to ensure the stability of the new sprout, and form the nascent vascular lumen (Fig. 1) (Gerhardt et al. 2003; Dejana et al. 2009; Iruela-Arispe and Davis 2009; Phng and Gerhardt 2009).

Additionally to the morphologic and functional differences, tip and stalk cells exhibit distinct gene expression profiles. Several recent transcriptional profiling efforts established a list of genes enriched in tip cells, including cellsurface receptors, growth factors, neuronal guidance receptors, and matrix-degrading proteases, as well as matrix components and more. 
Examples are Dll4, VEGFR2, VEGFR3, PDGFB, Ang-2, UNC5B, CXCR4, and Nidogen-2 (Gerhardt et al. 2003; Claxton and Fruttiger 2004; Lu et al. 2004; Tammela et al. 2008). Current efforts aim to decipher the functional relevance of the differential expression between tip and stalk cells for the coordinated behavior of the endothelial cells in the nascent sprout.

One of the first questions that arise from the observation of different endothelial cell phenotypes in the vascular sprout is: How are these cellular phenotypes specified? Studies in mouse and zebrafish development, in in vitro sprouting assays and in tumor angiogenesis, illustrate that the VEGF and Notch signaling pathways are fundamental for the specification of the endothelial cells into tip and stalk cells during the angiogenic sprouting process in physiological and pathological conditions (Gerhardt et al. 2003; Noguera-Troise et al. 2006; Ridgway et al. 2006; Hellstrom et al. 2007b; Leslie et al. 2007; Lobov et al. 2007; Siekmann and Lawson 2007; Suchting et al. 2007; Phng and Gerhardt 2009; Phng et al. 2009). Before discussing how VEGF and Notch engage in this process, we will briefly summarize key aspects of each signaling pathway.

\section{VEGF SIGNALING PATHWAY}

The vascular endothelial growth factor (VEGF) signaling pathway is essential for the regulation of sprouting angiogenesis in physiological and pathological conditions, controlling multiple aspects of endothelial behavior such as endothelial differentiation, migration, proliferation, survival, and permeability control (Fig. 2) (Ferrara et al. 2003).

In mammals, the VEGF family of growth factors encompasses six secreted dimeric glycoproteins (VEGF-A, -B, -C, -D, -E, and placenta growth factor $[\mathrm{PlGF}])$, which display distinct affinities for three tyrosine kinase receptors (VEGF receptor 1 [VEGFR1], 2 [VEGFR2], and 3 [VEGFR3]) (Fig. 2). The VEGF ligands are expressed in many cells and tissues, whereas the receptors were initially considered endothelial-specific. VEGFR1 and 2 are most strongly expressed in vascular endothelial cells but are also expressed in myeloid cells and neurons
(Barleon et al. 1996; Bellon et al. 2010; Muramatsu et al. 2010). In the adult, VEGFR3 is restricted to the lymphatic endothelium. However, activated blood endothelial cells in the embryo and during postnatal and tumor angiogenesis up-regulate VEGFR3 expression and signaling (Tammela et al. 2008).

Among the different ligands, VEGF-A is most prominently involved in the angiogenic process. VEGF-A expression is induced by hypoxic conditions (in a hypoxia-inducible factor Hif1/2-dependent manner), cytokines, growth factors, hormones, oncogenes, and tumor-suppressor genes (Dvorak 2005). Different VEGF-A splice isoforms have been reported in human and mouse (Tischer et al. 1991). These splice variants differ in their tissue distribution because of the presence or absence of carboxy-terminal heparan-sulfate-binding retention motifs that mediate interactions with cell surface and extracellular matrix proteoglycans (Park et al. 1993). All VEGF-A isoforms interact specifically with VEGFR1 and VEGFR2 but show highest affinity for binding to VEGFR1. Nevertheless, the tyrosine kinase activity of VEGFR2 is the main mediator of VEGF-A signaling during sprouting angiogenesis (Fig. 2) (Takahashi and Shibuya 2005; Olsson et al. 2006). VEGF-C-activating VEGFR3 has also been shown to mediate proangiogenic signaling, and the processed form of VEGF-C can also activate VEGFR2. In brief, the VEGF ligand-receptor interaction induces dimerization of the VEGF receptor, which, in turn, results in the autophosphorylation of different tyrosine residues that recruit $\mathrm{SH}$-2-containing adaptors and downstream kinases. Successively, this process activates a variety of downstream signaling pathways that regulate endothelial cell migration, survival, proliferation, and tube formation (Fig. 2).

In contrast to VEGFR2, VEGFR1 has very weak kinase activity and acts as a decoy receptor, competitively reducing VEGF binding to VEGFR2 and therefore limiting the activity of VEGF pathway in the vascular endothelial cells (Park et al. 1994). In addition, alternative splicing of VEGFR1 produces a soluble isoform of this receptor (sVEGFR1) that sequesters VEGF 

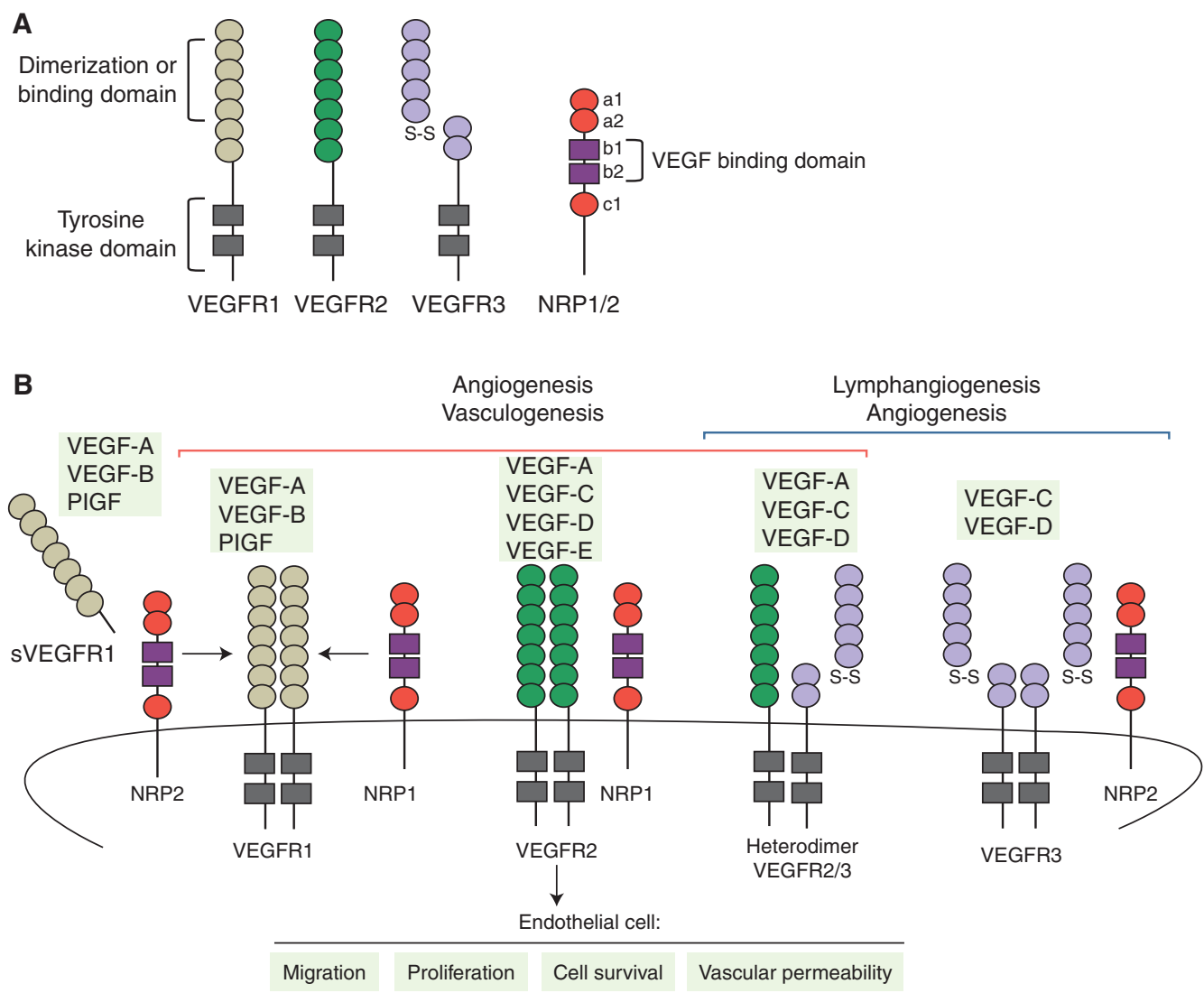

Figure 2. VEGFs, VEGF receptors, and coreceptors. (A) Outline of the structural domains of the different VEGFRs and coreceptors Nrp1 and Nrp2. (B) Schematic representation of the binding specificity of the different VEGF family members (VEGF-A, -B, -C, -D, -E, and PlGF) to the tyrosine kinase receptors, VEGFR1, VEGFR2, and VEGFR3. Interactions between VEGFRs and the coreceptors Nrp1 or Nrp2 are also shown in the figure. Activation of VEGFR1 and VEGFR2 regulates vasculogenesis and angiogenesis. However, activation of VEGFR3 stimulates lymphangiogenesis and embryonic angiogenesis. In particular, during sprouting angiogenesis VEGFR2 is the principal mediator of VEGF-A signaling, activating a variety of downstream signaling pathways that regulate endothelial cell migration, survival, proliferation, and tube formation. In contrast, VEGFR1 or sVEGFR1, acting as a decoy receptor, limits the VEGF activity in the vascular endothelium.

in the extracellular medium and thereby modulates VEGF signaling in the vascular endothelium (Tanaka et al. 1997). Furthermore, the cell-surface glycoproteins neuropilin1 (Nrp1) and neuropilin2 (Nrp2), originally identified as receptors for semaphorins, also modulate the VEGF signaling output. Both proteins act as VEGF non-kinase coreceptors, enhancing the binding activity of VEGF to VEGFR1 and 2 in the case of Nrp1, and of VEGF-C to VEGFR3 in the case of Nrp2 (Fig. 2) (Ferrara et al. 2003; Takahashi and Shibuya 2005).
Direct evidence for the implication of VEGF ligand and receptors in vasculogenesis and angiogenesis comes from the study of knockout mice for the VEGF ligand and the different VEGFRs genes. In general, homozygous deletion for the VEGF-A gene or any of the VEGFRs genes involved in the VEGF signaling pathway leads to embryonic death in utero between embryonic days 8.5 (E8.5) and E10.5, as a consequence of abnormal vascular development (Fong et al. 1995; Shalaby et al. 1995; Carmeliet et al. 1996; Ferrara et al. 1996; Dumont et al. 
1998). Importantly, embryonic lethality between days E11 and E12 has also been observed associated with the heterozygous deletion of VEGF-A (Carmeliet et al. 1996; Ferrara et al. 1996). As is discussed below, VEGF-A and Dll4 (Notch pathway ligand) are the only proteins of both pathways for which the heterozygosity results in a lethal embryonic phenotype, highlighting the essential and unique role of both proteins during angiogenesis. In contrast, deletion of VEGF-B, -C, or PlGF genes produces only subtle vascular phenotypes during development (Autiero et al. 2003; Reichelt et al. 2003).

\section{NOTCH SIGNALING PATHWAY}

The Notch pathway is an evolutionarily conserved intercellular contact-dependent signaling mechanism involved in multiple cell fate decisions and patterning processes during normal development. Among other functions, Notch signaling has been implicated in cell fate determination and differentiation of epithelial, neuronal, bone, blood, and most recently, endothelial cells (Karsan 2005; Bray 2006; Louvi and Artavanis-Tsakonas 2006; Radtke et al. 2006).

In vertebrates, four Notch receptors (from Notch1 to Notch4) and five Notch transmembrane ligands (Jagged1 and Jagged2, homologs to Serrate, and Delta-like ligand 1 [Dll1], 3 [Dll3], and 4 [Dll4]) constitute the core components of the Notch pathway (Ellisen et al. 1991; Weinmaster et al. 1992; Lardelli et al. 1994; Bettenhausen and Gossler 1995; Lindsell et al. 1995; Shawber et al. 1996; Uyttendaele et al. 1996; Dunwoodie et al. 1997; Rao et al. 2000; Shutter et al. 2000; Mailhos et al. 2001). Notch signaling begins with receptor-ligand interactions between neighboring cells. This interaction triggers a series of proteolytic cleavages of the Notch receptors. The final one, catalyzed by the $\gamma$-secretase complex, releases the active Notch intercellular domain (NICD) from the cell membrane (Weinmaster 1998; Mumm and Kopan 2000). Subsequently, NICD translocates to the nucleus, where it interacts directly with the transcription factor
CSL (also known as CBF1, Su [H], or Lag2). In absence of NICD, CSL functions as a transcriptional repressor through association with a corepressor complex that contains, among other components, histone deacetylases (Kao et al. 1998). Following binding of NICD to CSL, the corepressor complex is converted into an activation complex by displacing corepressors and recruiting coactivators. NICD, CSL, Mastermind-like (MAML) polypeptides, and the histone acetylase CBP/p300 are key components of the Notch transcriptional activator complex (Fryer et al. 2002; Jeffries et al. 2002). Recruitment of the coactivator complex to promoters containing CSL-binding elements induces transcriptional gene activation. This signaling mechanism is known as the "canonical Notch pathway" (Fig. 3). Hairy/enhancer of split (HES) and HES-related proteins (HEY/HRT/HERP) family genes are wellcharacterized direct target genes of Notch signaling (Nakagawa et al. 2000; Davis and Turner 2001; Iso et al. 2003). Moreover, the Dll4 ligand itself is also a target gene regulated by the Notch signaling pathway (Uyttendaele et al. 1996; Sainson et al. 2005).

Multiple observations indicate that the Notch signaling pathway plays a key role at different stages of vascular development. The Notch receptors 1 and 4 and also four of the five different ligands are expressed in the vasculature (Hofmann and Luisa Iruela-Arispe 2007). Furthermore, global knockout mice for Notch1 and Notch1/Notch4, as well as Jagged 1, die in utero, between E9.5 and E10.5, displaying severe vascular abnormalities produced by the lack of capacity to remodel the primordial vascular plexus into a hierarchical network (Xue et al. 1999; Krebs et al. 2000). Similarly to knockout studies, mice with a constitutive endothelium-specific expression of an activated allele for Notch4 (Notch4/int3) die during embryonic development, at day E10.5, and show vascular remodeling abnormalities reminiscent of those observed in Notch1-deficient mice (Uyttendaele et al. 2001). Moreover, mice deficient in Dll4 ligand die during early embryogenesis from vascular defects similar to those of Notch1/Notch4-deficient mice. 


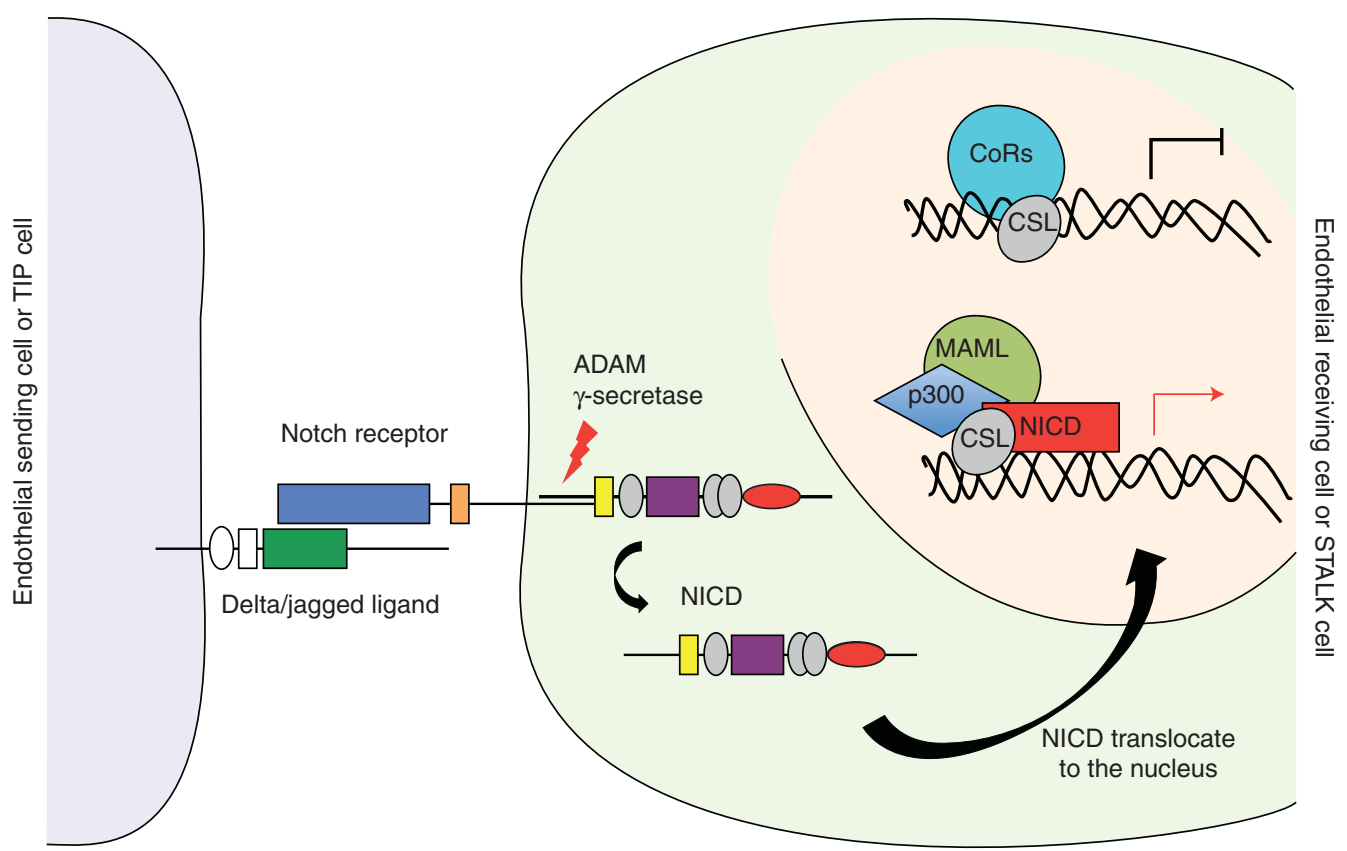

Figure 3. Canonical Notch signaling pathway. The Notch pathway is an evolutionarily conserved intercellular signaling mechanism implicated in cell fate determination and differentiation of endothelial cells. Notch signaling begins with receptor-ligand interaction between neighboring cells. This interaction triggers a series of proteolytic cleavages of the Notch receptor. The final one, catalyzed by the $\gamma$-secretase complex, releases the active Notch intercellular domain (NICD) from the cell membrane. NICD is translocated to the nucleus, where it interacts directly with the transcription factor CSL. Following binding of NICD to CSL, the repressor complex is converted into an activating complex by displacing corepressors and recruiting coactivators. After the coactivator complex is recruited, the transcription of promoters that contains CSL-binding elements is induced. Hairy/enhancer of split (HES) and HES-related proteins (HEY/HRT/HERP) family genes are included among the target genes of Notch signaling. Dll4 ligand is also a target gene regulated by the Notch signaling pathway.

Surprisingly, the genetic requirement of Dll4 is dose-dependent, and heterozygous Dll4 deletion is also lethal on most genetic backgrounds. Haploinsufficiency of Dll4 ligand results in vascular remodeling defects, arteriovenous malformation, and an incomplete formation of arteries (Duarte et al. 2004; Gale et al. 2004; Krebs et al. 2004). Moreover, Dll4 ${ }^{+/-}$mice show an increase in the number of vascular sprouts and vessel branches in the growing front of some vascular beds, such as yolk sac (Gale et al. 2004). It is important to note that the Dll4 ligand is the only Notch pathway component showing haploinsufficiency (Duarte et al. 2004; Gale et al. 2004; Krebs et al. 2004), highlighting the particular importance of Dll4 in vascular development. Furthermore, endothelial-specific deletion of CSL leads to similar defects as in Notch1, Notch1/Notch4, or Dll4 knockout mice. Additionally, simultaneous inactivation of two transcriptional genes regulated by the Notch signaling pathway, Heyl and Hey2, also results in embryonic lethality due to vascular defects (Fisher et al. 2003).

In sum, these different phenotypes show that the Notch pathway must be tightly regulated to ensure proper vascular formation during embryonic development, postnatal angiogenesis, and, as we will discuss below, during pathological angiogenesis (Limbourg et al. 2005; Noguera-Troise et al. 2006; Ridgway et al. 2006; Li et al. 2007; Takeshita et al. 2007). 
VEGF and Notch in Tip and Stalk Cell Selection

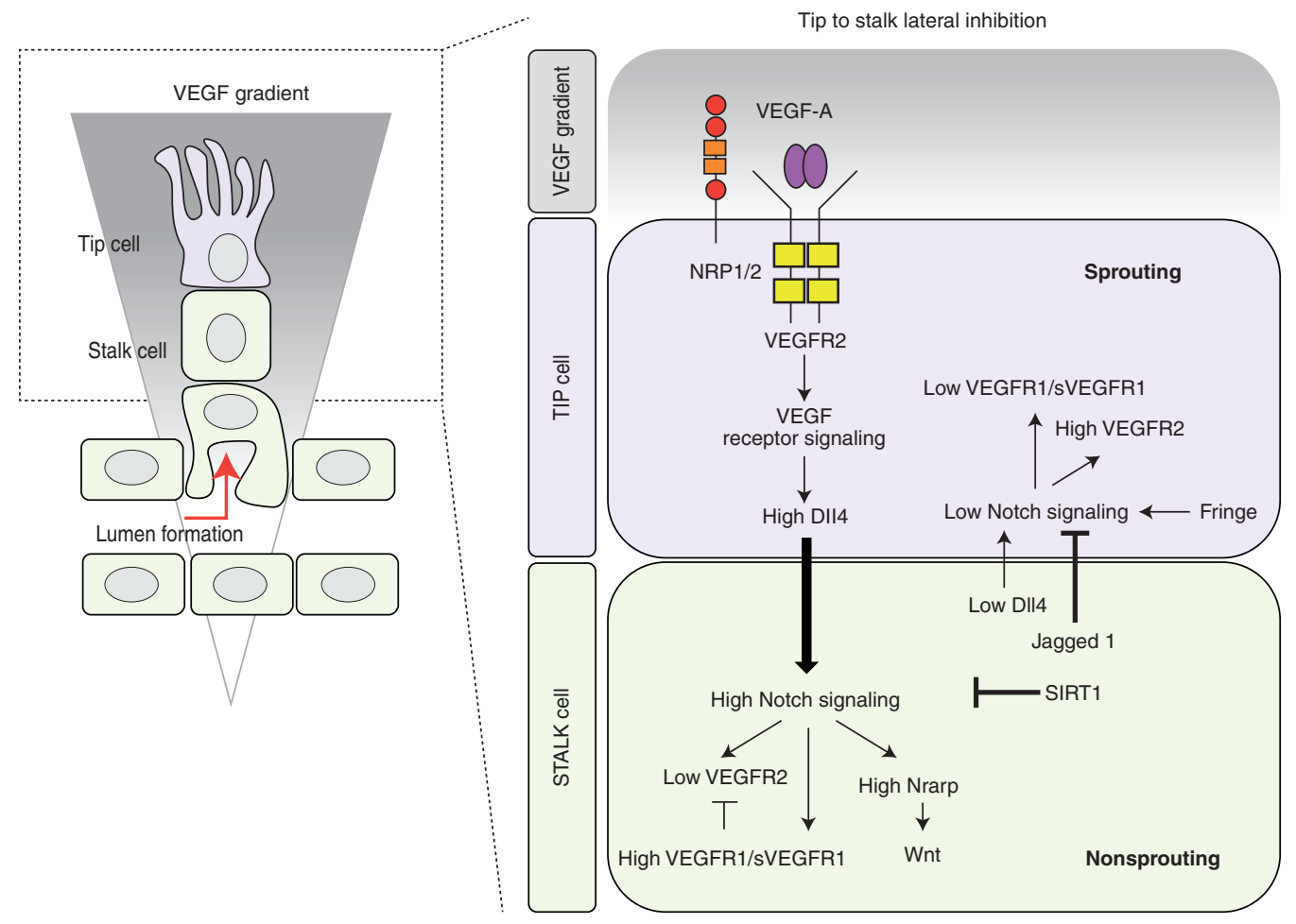

Figure 4. Tip/stalk cell specification during sprouting angiogenesis. During sprouting angiogenesis, VEGF and Notch signaling pathways are implicated in the specification of tip and stalk cells in the vascular endothelium. VEGF interacts with VEGFR2, expressed at the surface of the endothelial cells of the quiescent vessels. Nrp1 modulates the VEGF signaling output, enhancing the binding activity and signaling of VEGF through VEGFR2. Under VEGF stimulation, Dll4 expression is up-regulated in the tip cells. In turn, Dll4 ligand activates Notch signaling in the stalk, consequently suppressing the tip cell phenotype. Notch signaling activation reduces VEGFR2 expression and increases VEGFR1/sVEGFR1 levels as well as the expression of different Notch target genes (e.g., Notch-regulated ankyrin repeat protein [Nrarp]). In contrast, the tip cell receives low Notch signaling, allowing high expression of VEGFR2 and Nrp1, but low VEGFR1. Contrary to Dll4, Jagged1 ligand is expressed by the stalk cells. Jagged1 antagonizes Dll4-Notch signaling in the sprouting front when the Notch receptor is modified by the glycosyltranferase Fringe, thereby enhancing differential Notch activity between tip and stalk cells. The duration and amplitude of the Notch signal are modulated by the histone deacetylase SIRT1, which, by direct deacetylation, primes the Notch intracellular domain for ubiquitination and degradation.

\section{IMPLICATION OF VEGF AND NOTCH PATHWAY ON TIP/STALK SELECTION}

VEGF-A and Notch signaling pathways are key players governing tip and stalk cell behavior (Fig. 4).

Normal sprouting angiogenesis in the mouse retina requires a gradient of the proangiogenic factor VEGF-A (Ruhrberg et al. 2002; Gerhardt et al. 2003). This local VEGF-A gradient is produced by the preformed astrocyte network that serves as a guiding scaffold for the developing retinal plexus (Fruttiger 2002; Gerhardt et al. 2003). In fact, the tip cells are closely attached to the astrocytes, and their filopodia extend along the astrocytes toward higher VEGF-A concentrations in this gradient (Gerhardt et al. 2003). Interestingly, if VEGF-A stimulation is blocked using sVEGFR1 or neutralizing the signaling through VEGFR2 with antibodies, the tip cell filopodia are completely retracted in the sprouting retinal front 
(Gerhardt et al. 2003; Suchting et al. 2007), preventing tip cell migration and thus progression of vascular sprouting seizes (Gerhardt et al. 2003). In contrast, stimulation of quiescent vessels with VEGF-A induces filopodia formation and tip cell gene expression (Hellstrom et al. 2007a), together illustrating that VEGF-A is both necessary and sufficient to induce endothelial tip cells. Similar observations in zebrafish embryogenesis (Leslie et al. 2007) and other tissues in the mouse confirm the general importance of this concept.

If VEGF-A induces tip cell formation, it is surprising to see that tip cells are normally not formed by adjacent endothelial cells but form at characteristic intervals, enabling adequately spaced branching and sprouting. The molecular mechanism responsible for the fact that not all endothelial cells stimulated by VEGF become tip cells is based on the activity of Dll4/Notch signaling (Fig. 4).

Under physiological conditions, short-term administration of $\gamma$-secretase inhibitors (GSIs), which potently block Notch signaling, or pharmacological inhibition of Dll4/Notch interactions with a neutralizing antibody (Dll4-Fc) dramatically increases sprouting, branching, and filopodia formation at the leading front of the retinal vascular plexus in development, resulting in a much denser and more interconnected plexus (Fig. 5) (Hellstrom et al. 2007b; Lobov et al. 2007; Suchting et al. 2007). The hypersprouting phenotype correlates with an increase in endothelial cells positive for the tip cell markers PDGFB or UNC5B and the number of endothelial filopodia protrusions, indicating increased tip cell formation in the absence of Notch signaling (Fig. 5) (Hellstrom et al. 2007b; Suchting et al. 2007). Similar effects have been reported in the postnatal mouse retina and embryonic hindbrain vascularization after genetic deletion of one Dll4 allele or endothelial-specific Notch1 loss of function (VEcad$\mathrm{CreER}^{\mathrm{T} 2} / \mathrm{R} 26 \mathrm{R} / \mathrm{Notch}^{\mathrm{fl} / \mathrm{fl}}$ mice) (Hellstrom et al. 2007b; Lobov et al. 2007; Suchting et al. 2007). Both the pharmacological inhibition and genetic studies illustrate that the Dll4/ Notch pathway critically regulates the formation of an adequate ratio of tip and stalk cells by suppressing tip cell formation in adjacent cells (Figs. 4,5). Notch gain-of-function studies further support this idea; activation of Notch signaling using a synthetic Jagged 1 ligand peptide reduces filopodia formation and branching, suggesting a decrease in the number of endothelial cells that acquire tip cell behavior (Hellstrom et al. 2007b).

Several studies in zebrafish embryogenesis illustrated that the role of Notch signaling in angiogenesis is evolutionarily conserved (Leslie et al. 2007; Siekmann and Lawson 2007). Knocking down, with a morpholino oligonucleotide, the translation of Rbpsuh protein, a DNA-binding protein that mediates transcription of Notch target genes (Lecourtois and Schweisguth 1995) (known as CSL protein in mice), results in excessive sprouting and branching of the segmental arteries. Additionally, more endothelial cells in the arteries display a migratory behavior, typically restricted to the leading tip cells. These cells also show greatly increased filopodia activity and up-regulation of tip cell markers such as VEGFR3 (Siekmann and Lawson 2007). GSI treatment, as well as Dll4, or Notch1b loss-of-function phenocopies the segmental artery defects associated with Rbpsuh loss of function, whereas overactivation of the Notch pathway suppresses angiogenesis (Leslie et al. 2007; Siekmann and Lawson 2007). Transplantation experiments illustrated that knockdown of active Notch signaling promotes tip cell formation, whereas overexpression of active Notch inhibits tip cell formation in a cell-autonomous manner, illustrating that the activation status of Notch signaling quantitatively determines the ability of individual cells to become tip or stalk cells within the sprout.

Dll4 is not the only Notch ligand involved in tip cell regulation. Recent studies showed that Jagged 1 is more strongly expressed in stalk cells (Hofmann and Luisa Iruela-Arispe 2007; Benedito et al. 2009). Genetic deletion or endothelial overexpression of Jagged1 in vivo resulted in dramatically reduced or increased sprouting, respectively (Fig. 5). Surprisingly, endothelial Notch signaling is more active in the absence of Jagged1, indicating that Jagged 1 negatively 


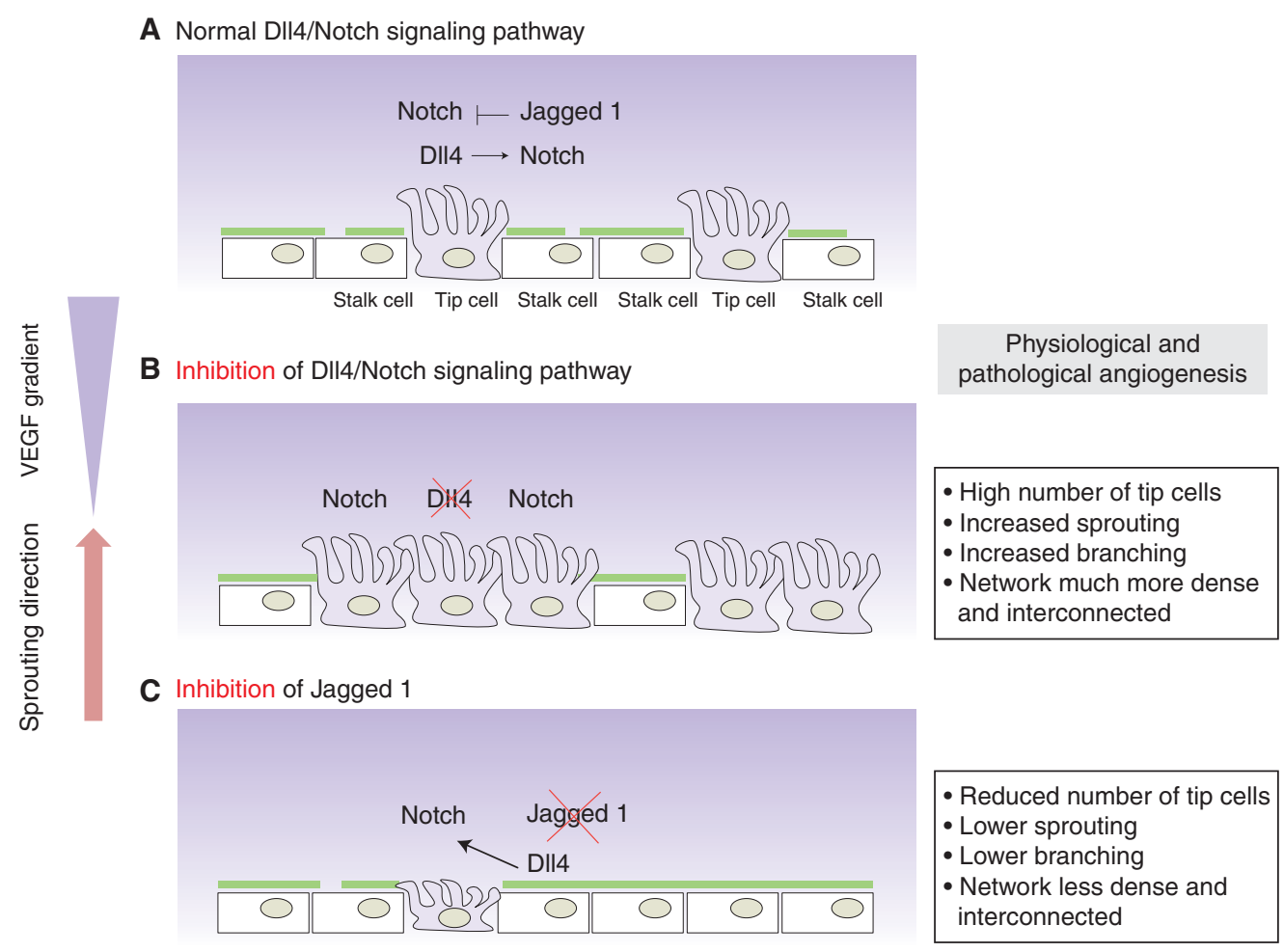

Figure 5. Dll4 and Jagged1 show antagonistic function during sprouting angiogenesis. Tip/stalk cell selection is mediated via Dll4/Notch lateral inhibition between the ECs that constitute the vasculature, resulting in the typical salt-and-pepper distribution of tip cells along the vascular endothelium. (A) For a detailed explanation about Dll4/Notch lateral inhibition see Figure 4. (B) Genetic or pharmacological inhibition of Dll4 deregulates the tip/stalk selection process; dramatically increases the number of tip cells, the number of sprouts and branching, resulting in a hyperdense and interconnected plexus. $(C)$ The opposite observation has been made after Jagged 1 inhibition in physiological and pathological angiogenesis, as Jagged1 antagonizes reciprocal Dll4-mediated Notch activation from the stalk to the tip cell.

regulates Notch activity (Figs. 4 and 5). In vitro studies confirmed that Jaggedl antagonizes Dll4-Notch signaling, suggesting, together with the complementary distribution of Dll4 and Jagged in the growing vascular plexus, that Jagged 1 enhances differential Notch activity by competitively interfering with the ability of Dll4 expressed by stalk cells to activate Notch in tip cells (Figs. 4 and 5) (Benedito et al. 2009). Intriguingly, the investigators show that the differential ability of Jagged 1 and Dll4 ligands to activate Notch is dependent on the glycosyltransferase Fringe. Whereas the glycosylated Notch receptor shows strong activation by Dll4 and competitive inhibition by Jagged1, the unglycosylated receptor in the absence of
Fringe can be activated by Jagged1 (Fig. 4) (Benedito et al. 2009). Exactly how this glycosylation event by Fringe might be controlled and whether it can locally function to fine-tune Notch-mediated vascular density remain to be shown. Nevertheless, the differential expression and action of Dll4 and Jagged 1 illustrate that the output of the Notch signaling pathway, which appears to function as a central regulator of vascular branching, can be modulated not only by the quantity of individual ligands, but also by their activity profile when interacting with the receptor. As we see below, the Notch output can further be regulated by multiple feedback mechanisms that affect both the quantity and duration of Notch signaling. 
VEGF and Notch signaling have, in addition to their role in developmental and physiological angiogenesis, also been implied in tip/stalk specification during pathological angiogenesis, such as ischemic retinopathy or cancer (Noguera-Troise et al. 2006; Ridgway et al. 2006; Lobov et al. 2007).

In the murine model of oxygen-induced ischemic retinopathy (OIR), in which neovascularization is triggered by initial oxygeninduced regression of central vessels followed by ischemia, consequential high VEGF-A levels, and thus aberrant epiretinal vascular tuft formation (Smith et al. 1994), suppression of Notch signaling (Dll4-Fc) greatly enhances sprouting and revascularization of the ischemic central retina (Fig. 5) (Lobov et al. 2007).

In tumor angiogenesis, many studies on preclinical rodent models initially reported effective reduction of angiogenesis and tumor growth following inhibition of the VEGFVEGFR pathway (Kim et al. 1993; Holash et al. 2002; Ferrara 2004; Rudge et al. 2005). However, more recent experimental work and the cumulative experience in the clinic have been rather disappointing, because the effective response is often absent or very transient (Kerbel et al. 2001; Casanovas et al. 2005; Jain et al. 2006). According to current concepts, the inhibition of VEGF-A or VEGFR signaling often leads to resistance because tumor cells use alternative pathways to promote angiogenesis. The observation that inhibition of Notch signaling in tumor endothelium can restore the sensitivity of tumors to anti-VEGF therapy in mouse models raised considerable interest and new hopes for antiangiogenic tumor therapy in humans (Noguera-Troise et al. 2006; Ridgway et al. 2006).

Dll4 ligand has been observed to be strongly expressed in the tumor vasculature (Mailhos et al. 2001; Gale et al. 2004; Patel et al. 2005; Scehnet et al. 2007), similar to active angiogenic regions in development (Lobov et al. 2007). Blockade of Notch signaling by retroviral or pharmacological delivery of Dll4-Fc or anti-Dll4 antibodies significantly increased vessel branching and density of the tumor vasculature in multiple xenograft models (Fig. 5)
(Noguera-Troise et al. 2006; Ridgway et al. 2006; Li et al. 2007; Scehnet et al. 2007). Interestingly, this correlates with many new small sprouts and filopodia, suggesting that more endothelial cells are acquiring the tip cell phenotype (Noguera-Troise et al. 2006). Similar results are observed in tumor xenografts in Dll4 heterozygous mice (Fig. 5) (Gale et al. 2004). In contrast, Notch signaling overactivation leads an unbranched and less dense tumor vasculature devoid of sprouts and filopodia (Noguera-Troise et al. 2006; Li et al. 2007). Paradoxically, in the absence of functional Notch signaling, the tumor growth is reduced despite the extensively abundant and dense vessel network (Noguera-Troise et al. 2006; Scehnet et al. 2007; Hoey et al. 2009; Li et al. 2010). In fact, this vessel network is poorly functional and fails to deliver oxygen to the tumors as a consequence of poor vessel perfusion (Noguera-Troise et al. 2006; Ridgway et al. 2006; Scehnet et al. 2007). Moreover, the vessels have a narrow caliber with decreased or absent lumen and reduced perycite recruitment, indicating defective vascular maturation (Scehnet et al. 2007). In contrast, overexpression of Dll4 and therefore increased Notch activation resulted in reduced tumor sprouting and angiogenesis, but increased vessel diameter and better perfusion and oxygenation, consequently reducing tumor cell death and accelerating tumor growth (Li et al. 2010).

Jagged1, which is reportedly expressed by some tumor cells, can also induce angiogenesis and affect tumor growth in different tumor models (Zeng et al. 2005; Funahashi et al. 2008). In line with its role in physiological conditions, tumor cell Jagged1 appears to antagonize endothelial Dll4 functions during tumor angiogenesis (Fig. 5) (Benedito et al. 2009). Moreover, the Dll1 ligand has also been reported to be involved in pathological angiogenesis and in arterial differentiation, but we currently lack detailed information about its precise role in vascular patterning (Takeshita et al. 2007; Sorensen et al. 2009).

Taken together, the observations obtained in the developing mouse retina and zebrafish embryo illustrate that Notch signaling acts as 
a negative regulator of VEGF-induced angiogenesis and is essential for proper vascular morphogenesis. Moreover, these data indicate that the tip/stalk specification principle, which works during physiological angiogenesis, also applies to pathological sprouting angiogenesis (Figs. 4,5).

\section{CROSS TALK BETWEEN THE VEGF AND NOTCH SIGNALING PATHWAYS}

The VEGF and Notch signaling pathways are both key regulators of the angiogenic process, being both involved in the specification of the tip and stalk cell phenotype (Fig. 4). It is therefore imperative that we ask how these two pathways work together to achieve functional patterning during sprouting angiogenesis.

Several lines of evidence indicate that VEGF signaling acts upstream of the Notch pathway during physiological and pathological angiogenesis (Stone et al. 1995; Lawson et al. 2002; Patel et al. 2005; Ridgway et al. 2006; Lobov et al. 2007), controlling the expression of different Notch components.

In in vitro studies, VEGF-A stimulation consistently increases the expression of Dll4 protein on the surface of human umbilical vein endothelial cells (HUVECs) (Ridgway et al. 2006). Also in human tumor samples, the expression of Dll4 mRNA increased up to ninefold in tumor blood vessels compared with vessels in the surrounding healthy tissue and correlated with increased local VEGF-A expression (Patel et al. 2005). Conversely, a rapid decrease of Dll4 expression has been reported in tumor blood vessels of different xenograft models after VEGF-A blockade (Noguera-Troise et al. 2006; Thurston and Kitajewski 2008).

Additionally to the observations reported before, hypoxic conditions, which prominently induce VEGF-A expression, appear to directly up-regulate Dll4 mRNA expression in different endothelial cell lines in an Hifl $\alpha$-dependent manner (Fig. 4) (Patel et al. 2005; Williams et al. 2006). Consistent with this notion, in the OIR model, high expression of Dll4 has been observed in veins and capillaries or sprouts in close proximity to the avascular-hypoxic regions (Lobov et al. 2007).

The same principles apply to normal development angiogenesis in the mouse retina, where high Dll4 expression is found at the vascular sprouting front, immediately adjacent to the avascular and hypoxic retinal periphery that expresses high levels of VEGF-A (Fig. 4) (Stone et al. 1995; Gerhardt et al. 2003; Liu et al. 2003; Lobov et al. 2007; Suchting et al. 2007). Retinal VEGF blockade using the VEGFTrap inhibited Dll4 mRNA expression in the growing retinal vascular plexus. Conversely, intravitreal injection of VEGF increases Dll4 expression, collectively showing that VEGF-A signaling in endothelial cells in vitro and in vivo quantitatively regulates Dll4 expression (Lobov et al. 2007; Suchting et al. 2007).

This is not only true for the sprouting front, because VEGF-A also acts upstream of Dll4 during the determination of arterial-endothelial cell fate in the zebrafish model (Lawson et al. 2002).

Exactly how VEGF-A signaling controls Dll4 is less well understood. In arteries, VEGF-A-mediated induction of Dll4 has been reported to involve both PI3K activation and the activity of the Forkhead family transcriptions factors FoxC1 and FoxC2 (Hayashi and Kume 2008). A recent study further identified a conserved transcriptional repressor complex comprising Tel and CtBP, which occupy the Dll4 promoter, and upon VEGF-A stimulation transiently disassemble, leading to temporal derepression of Dll4 transcription (Roukens et al. 2010). The timing of this event correlates with Erk1/2 phosphorylation, but the detailed activation pathway remains unclear.

In addition to VEGF-A acting upstream of Dll4, it has become clear that Notch, in turn, controls VEGF signaling. In general, all observations support the concept that Notch signaling via Dll4 principally acts as a negative feedback regulator to control VEGF-induced angiogenesis. Accordingly, endothelial Notch activation regulates the expression of the different VEGFRs (VEGFR1, 2, and 3) as well as the coreceptor Nrp1 (Fig. 4). Notch activation in HUVECS leads to VEGFR1 mRNA induction 
(Harrington et al. 2008; Funahashi et al. 2010). In contrast, VEGFR2 and Nrp1 mRNA is markedly reduced by Notch activation in HUVECs (Soker et al. 1998; Ridgway et al. 2006; Williams et al. 2006), indicating that Notch signaling is able to regulate how the endothelial cells respond to VEGF. In fact, it has been suggested that the reduction of VEGFR2 and Nrp1 expression may be responsible for the low proliferative and migratory response observed in Dll4overexpressing endothelial cells (Williams et al. 2006).

Similar interactions between VEGF and Notch pathways have been described in vivo. Down-regulation of VEGFR2 has been reported in blood vessels in Dll4-overexpressing tumors (Li et al. 2007). In contrast, genetic inactivation of one allele of Dll4 in mice significantly increases the expression of VEGFR2 mRNA while decreasing the levels of VEGFR1 mRNA (Suchting et al. 2007). Moreover, independent reports show that endothelial cells in Dll4 heterozygous retinas or in wild-type mice treated with $\gamma$-secretase inhibitors up-regulate VEGFR3 (Tammela et al. 2008). Equivalent results were obtained in zebrafish (Siekmann and Lawson 2007), where VEGFR3 is involved on driving sprouting angiogenesis in intersegmental arteries (Covassin et al. 2006; Tammela et al. 2008). Thus, Notch activity appears to modulate the sensitivity of endothelial cells to the inductive activity of VEGF-A, but up-regulating the decoy receptor VEGFR1 and downregulating the signaling receptors VEGFR2 and VEGFR3 (Fig. 4).

\section{TIP/STALK SELECTION MODEL}

In accordance with the experimental observations, the current concepts propose that the VEGF and Notch signaling pathways cooperate in tight coordination to specify and balance the tip and stalk cell phenotype between the endothelial cells that constitute the sprouts during the physiological and pathological angiogenic process. To this end, Notch signaling acts in a negative feedback loop with VEGF signaling during sprouting angiogenesis (Fig. 4). The model stipulates that the initial angiogenic response is induced by VEGF gradients established in the hypoxic tissues. Under VEGF stimulation, the endothelial cells of the pre-existing vessel become activated and compete for the tip cell position by Dll4/Notch signaling (Fig. 4).

Small stochastic differences in VEGFR2 expression or activity between endothelial cells, or differences in the local VEGF environment of the individual cells could initially give to some endothelial cells a competitive advantage against their neighbor to acquire the tip phenotype (Fig. 6). Indeed, the ability of an individual cell to become a tip cell appears to be strictly dependent on its VEGFR expression profile in comparison with that of the neighboring cells (Fig. 6). Specifically, in in vitro sprouting competition assays, in developmental analysis of chimeric mouse retinal vasculature, and in a new computational model of tip cell selection, endothelial cells with genetically encoded higher VEGFR2 or lower VEGFR1 levels showed a remarkable competitive advantage to develop and maintain the tip cell behavior compared to their wild-type neighbors (Fig. 6) (Jakobsson et al. 2010). Surprisingly, the VEGFR levels have no effect on migration speed or cell proliferation. Also, this competition is remarkably robust to changes in relative cell contribution, together illustrating that the mechanism of competition for the tip cell is not a migration race to the tip or a relative overgrowth of one population. Instead, it turns out that the VEGFR levels directly translate into Dll4 expression and that VEGFR levels only affect tip cell potential in the presence of active Notch signaling. In this "battle for the lead," the endothelial cell that expresses more Dll4 ligand than its neighbors acquires the tip cell phenotype because it can more effectively inhibit its neighbors in the growing sprout (Figs. 4 and 6). Recently, the role of VEGFR1 as negative regulator of tip cell formation has been confirmed also in zebrafish, indicating that Notch-mediated regulation of VEGFR1 represents an evolutionarily conserved mechanism to regulate competition for the tip position (Krueger et al. 2011).

The idea of competition via VEGFR and Dll4 levels are consistent with previously observed correlation between locally high 

A Tip cell potential
[VEGFR2] > [VEGFR1]
Scale of tip cell potential

B

In vitro competition assay

VEGFR $1^{+/-}>$WT $>$VEGFR2 $2^{+-}$
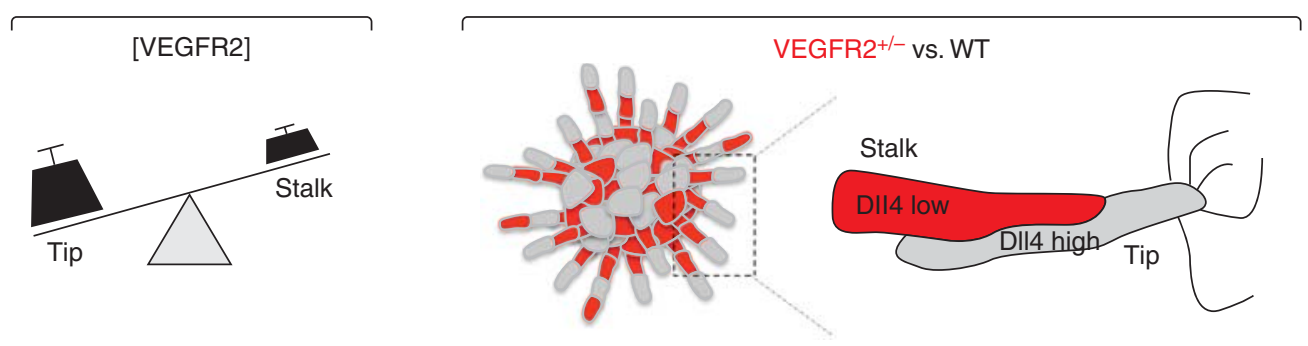

[VEGFR1]

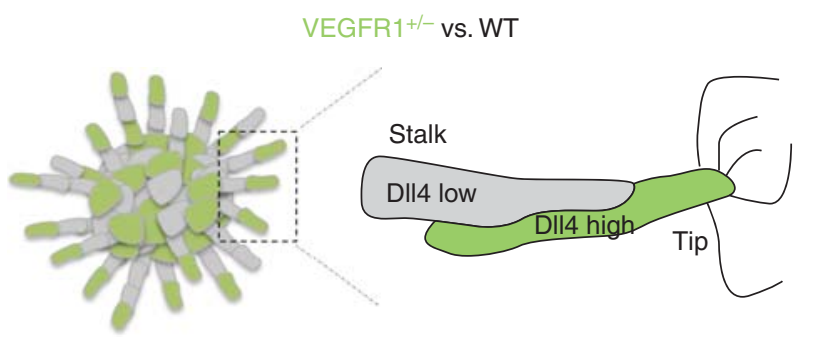

Figure 6. VEGFR1 and VEGFR2 levels regulate the tip cell potential in the vascular endothelium. (A) Schematic representation of how VEGFRs levels affect tip/stalk cell potential. (B) Outline of the genetic mosaic-sprouting assay in vitro between wild-type (WT) and VEGFR2 or VEGFR1 heterozygous endothelial cells. Cells with higher VEGFR2 levels or lower VEGFR1 levels preferentially acquire the lead position (tip cell) in the sprout. VEGFR levels modulate the expression of Dll4 ligand during the selection process. VEGFR2 ${ }^{+/}$cells produce less Dll4 mRNA and protein when competing with wild-type cells, which reduces their ability to compete for the tip cell phenotype. The opposite is true for VEGFR $1^{+/}$cells in competition with wild-type cells.

VEGF expression and endothelial Dll4 expression (Claxton and Fruttiger 2004). In situ hybridization in developing retinas showed the prevalent expression of Dll4 transcripts in tip cells and corresponding expression of Notch target genes in the stalk cells (Claxton and Fruttiger 2004; Hellstrom et al. 2007b; Hofmann and Luisa Iruela-Arispe 2007).

Earlier mosaic analysis using transplantation in zebrafish models or mosaic Cre-loxmediated recombination in the mouse retina also support the principles of Notch-mediated competition.
In mouse, inducible mosaic recombination of the Notch1 allele flanked by loxP sites, in combination with the R26R Cre-reporter allele (VEcad$\mathrm{CreER}^{\mathrm{T} 2} / \mathrm{R} 26 \mathrm{R} / \mathrm{Notch} 1^{\text {floxed/floxed }}$ mice), illustrated that Notch1-deficient endothelial cells dominate the tip cell position (Hellstrom et al. 2007b).

In zebrafish, Siekmann and Lawson (2007) transplanted either Notch-signaling-deficient or constitutively Notch-signaling-active cells into wild-type host embryos to investigate their position in the developing intersegmental vessels. Quantification revealed a robust 
overrepresentation of Notch-signaling-deficient cells in the tip cell position, whereas Notchactive cells were excluded from the tip position and instead were confined to the base of the sprouts (Siekmann and Lawson 2007).

More recently, mouse ES cells lacking one allele of Nrarp, a negative regulator of Notch, showed reduced ability to form tip cells when competing with wild-type embryonic stem (ES) cells in the three-dimensional (3D) sprouting assay. These results illustrate that even a small increase in Notch signaling robustly interferes with the ability of cells to compete with their neighbors for the tip (Jakobsson et al. 2010). Also, Dll4-heterozygous ES cells cannot compete with wild-type cells for the tip. In contrast, in a mosaic context, endothelial cells deficient for Jagged1 ligand preferentially acquire the tip cell position (Benedito et al. 2009), consistent with the idea that Jagged1-deficient cells will more efficiently activate Notch in neighboring cells. Altogether, the mosaic analyses in various model systems corroborate a model in which VEGFR signaling quantitatively regulates Dll4 levels, which, in turn, determine the tip cell potential of the individual cell in a competitive manner. A cell that in this process receives more Notch input will invariably adopt the stalk cell phenotype because it is effectively inhibited from becoming a tip cell (Fig. 4).

The spatial requirements of contactmediated "lateral inhibition" via Dll4/Notch signaling theoretically demand that, in a row of endothelial cells stimulated by VEGF-A, maximally two consecutive stalk cells can form between tip cells. A subsequent division of stalk cells should in theory lead to three or more stalk cells, which, however, cannot inhibit each other from becoming a tip cell. Any endothelial cell that is activated by VEGF-A and not directly inhibited by a neighbor expressing high levels of Dll4 will default to the tip cell phenotype and thus initiate a new sprout (Fig. 4). This fundamental principle is now believed to represent the key mechanism of spacing vascular sprouts during normal development.

An agent-based computational model of this VEGF-VEGFR-Dll4-Notch-VEGFR regulatory feedback loop between endothelial cells
(Bentley et al. 2008) strongly supports the theoretical model and illustrates that under appropriate VEGF stimulation, this feedback mechanism is sufficient to mediate tip-stalk selection (Bentley et al. 2008). However, the very same feedback regulation shows very different behavior when simulating pathologically high VEGF concentrations. Instead of establishing alternating tip and stalk cells, the endothelial cells synchronously oscillate between the two phenotypes and thus fail to coordinate a sprouting and branching process. Intriguingly, this emergent behavior of the computational model raises the possibility that the aberrant vascular patterning observed in pathological situations could be a consequence of local Notch oscillations in endothelial cell populations exposed to high VEGF-A concentrations. Such synchronous oscillations of Notch signaling occur in other developmental systems, most prominently during somitogenesis (Kageyama et al. 2007). Although experimental evidence for the existence of Notch oscillations in the endothelium is currently lacking, the implications warrant efforts to understand the dynamic control of Dll4/Notch signaling in more detail.

\section{TIP/STALK SELECTION IS DYNAMIC}

During the continued sprouting, branching, and anastomosis process as the vascular network expands, new tip cells will have to be formed, whereas others may convert to stalk cells. Indeed, emergent behavior in the computational model of tip/stalk selection illustrated that meeting of two tip cells during anastomosis will trigger renewed competition (Bentley et al. 2009). As a consequence of changing endothelial neighbors, previously inhibited stalk cells can be relieved from their inhibition and become new tip cells. Thus, endothelial tip and stalk cell specification does not represent permanent cell fate decisions but, rather, dynamic phenotypical specification in flux.

Time-lapse confocal microscopy of clonally labeled cell populations in zebrafish embryos in vivo and in $3 \mathrm{D}$ sprouting assays in vitro delivered new insight into the surprisingly dynamic behavior of tip and stalk cells within individual 
sprouts. Endothelial cells in the extending sprouts appear to engage in iterative or continued battles for the tip position, leading to frequent exchange of the tip cells. The precise reason for this behavior is not fully understood, but Notch signaling again appears to play a part in its regulation (Jakobsson et al. 2010).

The dynamic selection of phenotypes and continued competition must arguably serve an important function, because they come at considerable cost; stalk cells actively form lumen and must engage in a repolarization effort, to establish apical (luminal) and basal domains during tubulogenesis. However, if they frequently switch between the migratory, leading tip cell phenotype, and the lumen-forming stalk cell, the entire architecture of the developing vessel is in constant flux, defying the notion of stable cell identities and functions. Future efforts will therefore be focused on both understanding the molecular regulation of the dynamic behavior and unraveling its important biological function.

\section{FUTURE DIRECTIONS}

In this article, we have summarized key components and current concepts of the VEFG and Notch signaling pathways and how they critically regulate vascular patterning by controlling endothelial tip and stalk cell specification in sprouting angiogenesis. Despite the vast amount of literature on both pathways and the plethora of recent studies on their interactions in angiogenesis, many questions remain unanswered. Are tip and stalk cells universal concepts applicable to all areas of angiogenesis? What is the role of extracellular matrix in their behavior? How is the polarity of tip and stalk cells regulated? How is Dll4 expression dynamically controlled, and what is the ultimate effector of Notch determining the stalk cell phenotype? And in disease processes, does the prediction of synchronous Notch signaling oscillations hold true? Will we be able to identify novel critical parameters and regulators in the VEGF-Dll4/Notch feedback loop that will allow us to devise effective strategies for vascular normalization or antiangiogenesis therapy? The pace of recent development in this area, the growing number of researchers focusing on similar powerful developmental systems, and the integration of insights from computational models, developmental biology, and clinical studies raise hopes that we may soon be able to find answers to these and further questions.

\section{ACKNOWLEDGMENTS}

H.G. and R.B. are supported by Cancer Research UK, the Lister Institute of Preventive Medicine, the EMBO Young Investigator Programme, the Leducq Transatlantic Network ARTEMIS, and a HFSP Long-term Fellowship.

\section{REFERENCES}

Autiero M, Waltenberger J, Communi D, Kranz A, Moons L, Lambrechts D, Kroll J, Plaisance S, De Mol M, Bono F et al. 2003. Role of PlGF in the intra- and intermolecular cross talk between the VEGF receptors Flt1 and Flk1. Nat Med 9: 936-943.

Barleon B, Sozzani S, Zhou D, Weich HA, Mantovani A, Marme D. 1996. Migration of human monocytes in response to vascular endothelial growth factor (VEGF) is mediated via the VEGF receptor flt-1. Blood 87: 3336-3343.

Bellon A, Luchino J, Haigh K, Rougon G, Haigh J, Chauvet S, Mann F. 2010. VEGFR2 (KDR/Flk1) signalling mediates axon growth in response to semaphorin $3 \mathrm{E}$ in the developing brain. Neuron 66: 205-219.

Benedito R, Roca C, Sorensen I, Adams S, Gossler A, Fruttiger M, Adams RH. 2009. The notch ligands Dll4 and Jagged 1 have opposing effects on angiogenesis. Cell 137: $1124-1135$

Bentley K, Gerhardt H, Bates PA. 2008. Agent-based simulation of notch-mediated tip cell selection in angiogenic sprout initialisation. $J$ Theor Biol 250: 25-36.

Bentley K, Mariggi G, Gerhardt H, Bates PA. 2009. Tipping the balance: Robustness of tip cell selection, migration and fusion in angiogenesis. PLoS Comput Biol 5: e1000549. doi: 10.1371/journal.pcbi.1000549.

Bettenhausen B, Gossler A. 1995. Efficient isolation of novel mouse genes differentially expressed in early postimplantation embryos. Genomics 28: 436-441.

Bray SJ. 2006. Notch signalling: A simple pathway becomes complex. Nat Rev 7: 678-689.

Carmeliet P, Ferreira V, Breier G, Pollefeyt S, Kieckens L, Gertsenstein M, Fahrig M, Vandenhoeck A, Harpal K Eberhardt C, et al. 1996. Abnormal blood vessel development and lethality in embryos lacking a single VEGF allele. Nature 380: 435-439.

Casanovas O, Hicklin DJ, Bergers G, Hanahan D. 2005. Drug resistance by evasion of antiangiogenic targeting of VEGF signalling in late-stage pancreatic islet tumors. Cancer Cell 8: 299-309. 
Claxton S, Fruttiger M. 2004. Periodic Delta-like 4 expression in developing retinal arteries. Gene Expr Patterns 5: 123-127.

Covassin LD, Villefranc JA, Kacergis MC, Weinstein BM, Lawson ND. 2006. Distinct genetic interactions between multiple Vegf receptors are required for development of different blood vessel types in zebrafish. Proc Natl Acad Sci 103: 6554-6559.

Davis RL, Turner DL. 2001. Vertebrate hairy and Enhancer of split related proteins: Transcriptional repressors regulating cellular differentiation and embryonic patterning. Oncogene 20: 8342-8357.

Dejana E, Tournier-Lasserve E, Weinstein BM. 2009. The control of vascular integrity by endothelial cell junctions: Molecular basis and pathological implications. Dev Cell 16: $209-221$

Duarte A, Hirashima M, Benedito R, Trindade A, Diniz P, Bekman E, Costa L, Henrique D, Rossant J. 2004. Dosagesensitive requirement for mouse Dll4 in artery development. Genes Dev 18: 2474-2478.

Dumont DJ, Jussila L, Taipale J, Lymboussaki A, Mustonen T, Pajusola K, Breitman M, Alitalo K. 1998. Cardiovascular failure in mouse embryos deficient in VEGF receptor-3. Science 282: 946-949.

Dunwoodie SL, Henrique D, Harrison SM, Beddington RS. 1997. Mouse Dll3: A novel divergent Delta gene which may complement the function of other Delta homologues during early pattern formation in the mouse embryo. Development 124: 3065-3076.

Dvorak HF. 2005. Angiogenesis: Update 2005. J Thromb Haemost 3: 1835-1842.

Ellisen LW, Bird J, West DC, Soreng AL, Reynolds TC, Smith SD, Sklar J. 1991. TAN-1, the human homolog of the Drosophila notch gene, is broken by chromosomal translocations in T lymphoblastic neoplasms. Cell 66: 649-661.

Ferrara N. 2004. Vascular endothelial growth factor as a target for anticancer therapy. Oncologist 9: 2-10.

Ferrara N, Carver-Moore K, Chen H, Dowd M, Lu L, O'Shea KS, Powell-Braxton L, Hillan KJ, Moore MW. 1996. Heterozygous embryonic lethality induced by targeted inactivation of the VEGF gene. Nature 380: 439-442.

Ferrara N, Gerber HP, LeCouter J. 2003. The biology of VEGF and its receptors. Nat Med 9: 669-676.

Fisher ND, Hughes M, Gerhard-Herman M, Hollenberg NK. 2003. Flavanol-rich cocoa induces nitric-oxidedependent vasodilation in healthy humans. J Hypertens 21: 2281-2286.

Fong GH, Rossant J, Gertsenstein M, Breitman ML. 1995. Role of the Flt-1 receptor tyrosine kinase in regulating the assembly of vascular endothelium. Nature 376: $66-70$.

Fruttiger M. 2002. Development of the mouse retinal vasculature: Angiogenesis versus vasculogenesis. Invest Ophthalmol Vis Sci 43: 522-527.

Fryer CJ, Lamar E, Turbachova I, Kintner C, Jones KA. 2002. Mastermind mediates chromatin-specific transcription and turnover of the Notch enhancer complex. Genes Dev 16: 1397-1411.

Funahashi Y, Hernandez SL, Das I, Ahn A, Huang J, Vorontchikhina M, Sharma A, Kanamaru E, Borisenko V, Desilva DM, et al. 2008. A notch1 ectodomain construct inhibits endothelial notch signalling, tumor growth, and angiogenesis. Cancer Res 68: 4727-4735.

Funahashi Y, Shawber CJ, Vorontchikhina M, Sharma A, Outtz HH, Kitajewski J. 2010. Notch regulates the angiogenic response via induction of VEGFR-1.J Angiogenes Res 2: 3. doi: 10.1186/2040-2384-2-3.

Gale NW, Dominguez MG, Noguera I, Pan L, Hughes V, Valenzuela DM, Murphy AJ, Adams NC, Lin HC, Holash J, et al. 2004. Haploinsufficiency of delta-like 4 ligand results in embryonic lethality due to major defects in arterial and vascular development. Proc Natl Acad Sci 101: 15949-15954.

Gerhardt H, Golding M, Fruttiger M, Ruhrberg C, Lundkvist A, Abramsson A, Jeltsch M, Mitchell C, Alitalo K, Shima D, et al. 2003. VEGF guides angiogenic sprouting utilizing endothelial tip cell filopodia. J Cell Biol 161: $1163-1177$.

Harrington LS, Sainson RC, Williams CK, Taylor JM, Shi W, Li JL, Harris AL. 2008. Regulation of multiple angiogenic pathways by Dll4 and Notch in human umbilical vein endothelial cells. Microvasc Res 75: 144-154.

Hayashi H, Kume T. 2008. Foxc transcription factors directly regulate Dll4 and Hey2 expression by interacting with the VEGF-Notch signalling pathways in endothelial cells. PLoS ONE 3: e2401. doi: 10.1371/journal.pone.0002401.

Hellstrom M, Phng LK, Gerhardt H. 2007a. VEGF and Notch signalling: The yin and yang of angiogenic sprouting. Cell Adh Migr 1: 133-136.

Hellstrom M, Phng LK, Hofmann JJ, Wallgard E, Coultas L, Lindblom P, Alva J, Nilsson AK, Karlsson L, Gaiano N, et al. 2007b. Dll4 signalling through Notch1 regulates formation of tip cells during angiogenesis. Nature 445: 776-780.

Hoey T, Yen WC, Axelrod F, Basi J, Donigian L, Dylla S, Fitch-Bruhns M, Lazetic S, Park IK, Sato A, et al. 2009. DLL4 blockade inhibits tumor growth and reduces tumor-initiating cell frequency. Cell Stem Cell 5: $168-177$.

Hofmann JJ, Luisa Iruela-Arispe M. 2007. Notch expression patterns in the retina: An eye on receptor-ligand distribution during angiogenesis. Gene Expr Patterns 7: 461-470.

Holash J, Davis S, Papadopoulos N, Croll SD, Ho L, Russell M, Boland P, Leidich R, Hylton D, Burova E, et al. 2002. VEGF-Trap: A VEGF blocker with potent antitumor effects. Proc Natl Acad Sci 99: 11393-11398.

Iruela-Arispe ML, Davis GE. 2009. Cellular and molecular mechanisms of vascular lumen formation. Dev Cell 16: $222-231$.

Iso T, Kedes L, Hamamori Y. 2003. HES and HERP families: Multiple effectors of the Notch signalling pathway. J Cell Physiol 194: 237-255.

Isogai S, Lawson ND, Torrealday S, Horiguchi M, Weinstein BM. 2003. Angiogenic network formation in the developing vertebrate trunk. Development 130: 5281-5290.

Jain RK, Duda DG, Clark JW, Loeffler JS. 2006. Lessons from phase III clinical trials on anti-VEGF therapy for cancer. Nat Clin Pract Oncol 3: 24-40.

Jakobsson L, Franco CA, Bentley K, Collins RT, Ponsioen B, Aspalter IM, Rosewell I, Busse M, Thurston G, Medvinsky A, et al. 2010. Endothelial cells dynamically compete 
for the tip cell position during angiogenic sprouting. Nat Cell Biol 12: 943-953.

Jeffries S, Robbins DJ, Capobianco AJ. 2002. Characterization of a high-molecular-weight Notch complex in the nucleus of Notch(ic)-transformed RKE cells and in a human T-cell leukemia cell line. Mol Cell Biol 22: 3927-3941.

Kageyama R, Masamizu Y, Niwa Y. 2007. Oscillator mechanism of Notch pathway in the segmentation clock. Dev Dyn 236: 1403-1409.

Kao HY, Ordentlich P, Koyano-Nakagawa N, Tang Z, Downes M, Kintner CR, Evans RM, Kadesch T. 1998. A histone deacetylase corepressor complex regulates the Notch signal transduction pathway. Genes Dev 12: 2269-2277.

Karsan A. 2005. The role of notch in modeling and maintaining the vasculature. Can J Physiol Pharmacol 83: $14-23$.

Kerbel RS, Yu J, Tran J, Man S, Viloria-Petit A, Klement G, Coomber BL, Rak J. 2001. Possible mechanisms of acquired resistance to anti-angiogenic drugs: Implications for the use of combination therapy approaches. Cancer Metastasis Rev 20: 79-86.

Kim KJ, Li B, Winer J, Armanini M, Gillett N, Phillips HS, Ferrara N. 1993. Inhibition of vascular endothelial growth factor-induced angiogenesis suppresses tumour growth in vivo. Nature 362: 841-844.

Krebs LT, Xue Y, Norton CR, Shutter JR, Maguire M, Sundberg JP, Gallahan D, Closson V, Kitajewski J, Callahan R, et al. 2000. Notch signalling is essential for vascular morphogenesis in mice. Genes Dev 14: 1343-1352.

Krebs LT, Shutter JR, Tanigaki K, Honjo T, Stark KL, Gridley T. 2004. Haploinsufficient lethality and formation of arteriovenous malformations in Notch pathway mutants. Genes Dev 18: 2469-2473.

Krueger J, Liu D, Scholz K, Zimmer A, Shi Y, Klein C, Siekmann A, Schulte-Merker S, Cudmore M, Ahmed A, et al. 2011. Flt1 acts as a negative regulator of tip cell formation and branching morphogenesis in the zebrafish embryo. Development 138: 2111-2120.

Lardelli M, Dahlstrand J, Lendahl U. 1994. The novel Notch homologue mouse Notch 3 lacks specific epidermal growth factor-repeats and is expressed in proliferating neuroepithelium. Mech Dev 46: 123-136.

Lawson ND, Vogel AM, Weinstein BM. 2002. sonic hedgehog and vascular endothelial growth factor act upstream of the Notch pathway during arterial endothelial differentiation. Dev Cell 3: 127-136.

Lecourtois M, Schweisguth F. 1995. The neurogenic suppressor of hairless DNA-binding protein mediates the transcriptional activation of the enhancer of split complex genes triggered by Notch signalling. Genes Dev 9: 2598-2608.

Leslie JD, Ariza-McNaughton L, Bermange AL, McAdow R, Johnson SL, Lewis J. 2007. Endothelial signalling by the Notch ligand Delta-like 4 restricts angiogenesis. Development 134: 839-844.

Li JL, Sainson RC, Shi W, Leek R, Harrington LS, Preusser M, Biswas S, Turley H, Heikamp E, Hainfellner JA, et al. 2007. Delta-like 4 Notch ligand regulates tumor angiogenesis, improves tumor vascular function, and promotes tumor growth in vivo. Cancer Res 67: 11244-11253.

Li JL, Jubb AM, Harris AL. 2010. Targeting DLL4 in tumors shows preclinical activity but potentially significant toxicity. Future Oncol 6: 1099-1103.

Limbourg FP, Takeshita K, Radtke F, Bronson RT, Chin MT, Liao JK. 2005. Essential role of endothelial Notch1 in angiogenesis. Circulation 111: 1826-1832.

Lindsell CE, Shawber CJ, Boulter J, Weinmaster G. 1995. Jagged: A mammalian ligand that activates Notch1. Cell 80: 909-917.

Liu ZJ, Shirakawa T, Li Y, Soma A, Oka M, Dotto GP, Fairman RM, Velazquez OC, Herlyn M. 2003. Regulation of Notch1 and Dll4 by vascular endothelial growth factor in arterial endothelial cells: Implications for modulating arteriogenesis and angiogenesis. Mol Cell Biol 23: $14-25$.

Lobov IB, Renard RA, Papadopoulos N, Gale NW, Thurston G, Yancopoulos GD, Wiegand SJ. 2007. Delta-like ligand 4 (Dll4) is induced by VEGF as a negative regulator of angiogenic sprouting. Proc Natl Acad Sci 104: 32193224.

Louvi A, Artavanis-Tsakonas S. 2006. Notch signalling in vertebrate neural development. Nat Rev Neurosci 7: 93-102.

Lu X, Le Noble F, Yuan L, Jiang Q, De Lafarge B, Sugiyama D, Breant C, Claes F, De Smet F, Thomas JL, et al. 2004. The netrin receptor UNC5B mediates guidance events controlling morphogenesis of the vascular system. Nature 432: $179-186$.

Mailhos C, Modlich U, Lewis J, Harris A, Bicknell R, IshHorowicz D. 2001. Delta4, an endothelial specific notch ligand expressed at sites of physiological and tumor angiogenesis. Differentiation 69: 135-144.

Mumm JS, Kopan R. 2000. Notch signalling: From the outside in. Dev Biol 228: 151-165.

Muramatsu M, Yamamoto S, Osawa T, Shibuya M. 2010. Vascular endothelial growth factor receptor-1 signalling promotes mobilization of macrophage lineage cells from bone marrow and stimulates solid tumor growth. Cancer Res 70: 8211-8221.

Nakagawa O, McFadden DG, Nakagawa M, Yanagisawa H, Hu T, Srivastava D, Olson EN. 2000. Members of the HRT family of basic helix-loop-helix proteins act as transcriptional repressors downstream of Notch signalling. Proc Natl Acad Sci 97: 13655-13660.

Noguera-Troise I, Daly C, Papadopoulos NJ, Coetzee S, Boland P, Gale NW, Lin HC, Yancopoulos GD, Thurston G. 2006. Blockade of Dll4 inhibits tumour growth by promoting non-productive angiogenesis. Nature 444: 1032-1037.

Olsson AK, Dimberg A, Kreuger J, Claesson-Welsh L. 2006. VEGF receptor signalling-In control of vascular function. Nat Rev 7: 359-371.

Park JE, Keller GA, Ferrara N. 1993. The vascular endothelial growth factor (VEGF) isoforms: Differential deposition into the subepithelial extracellular matrix and bioactivity of extracellular matrix-bound VEGF. Mol Biol Cell 4: $1317-1326$.

Park JE, Chen HH, Winer J, Houck KA, Ferrara N. 1994. Placenta growth factor. Potentiation of vascular endothelial 
growth factor bioactivity, in vitro and in vivo, and high affinity binding to Flt-1 but not to Flk-1/KDR. J Biol Chem 269: 25646-25654.

Patel NS, Li JL, Generali D, Poulsom R, Cranston DW, Harris AL. 2005. Up-regulation of delta-like 4 ligand in human tumor vasculature and the role of basal expression in endothelial cell function. Cancer Res 65: 8690-8697.

Phng LK, Gerhardt H. 2009. Angiogenesis: A team effort coordinated by notch. Dev Cell 16: 196-208.

Phng LK, Potente M, Leslie JD, Babbage J, Nyqvist D, Lobov I, Ondr JK, Rao S, Lang RA, Thurston G, et al. 2009. Nrarp coordinates endothelial Notch and Wnt signalling to control vessel density in angiogenesis. Dev Cell 16: $70-82$.

Radtke F, Clevers H, Riccio O. 2006. From gut homeostasis to cancer. Curr Mol Med 6: 275-289.

Rao PK, Dorsch M, Chickering T, Zheng G, Jiang C, Goodearl A, Kadesch T, McCarthy S. 2000. Isolation and characterization of the notch ligand delta4. Exp Cell Res 260: 379-386.

Reichelt M, Shi S, Hayes M, Kay G, Batch J, Gole GA, Browning J. 2003. Vascular endothelial growth factor-B and retinal vascular development in the mouse. Clin Experiment Ophthalmol 31: 61-65.

Ridgway J, Zhang G, Wu Y, Stawicki S, Liang WC, Chanthery Y, Kowalski J, Watts RJ, Callahan C, Kasman I, et al. 2006. Inhibition of Dll4 signalling inhibits tumour growth by deregulating angiogenesis. Nature 444: 1083-1087.

Risau W. 1997. Mechanisms of angiogenesis. Nature 386: 671-674.

Roukens MG, Alloul-Ramdhani M, Baan B, Kobayashi K, Peterson-Maduro J, van Dam H, Schulte-Merker S, Baker DA. 2010. Control of endothelial sprouting by a Tel-CtBP complex. Nat Cell Biol 12: 933-942.

Rudge JS, Thurston G, Davis S, Papadopoulos N, Gale N, Wiegand SJ, Yancopoulos GD. 2005. VEGF trap as a novel antiangiogenic treatment currently in clinical trials for cancer and eye diseases, and VelociGene-based discovery of the next generation of angiogenesis targets. Cold Spring Harb Symp Quant Biol 70: 411-418.

Ruhrberg C, Gerhardt H, Golding M, Watson R, Ioannidou S, Fujisawa H, Betsholtz C, Shima DT. 2002. Spatially restricted patterning cues provided by heparin-binding VEGF-A control blood vessel branching morphogenesis. Genes Dev 16: 2684-2698.

Sainson RC, Aoto J, Nakatsu MN, Holderfield M, Conn E, Koller E, Hughes CC. 2005. Cell-autonomous notch signalling regulates endothelial cell branching and proliferation during vascular tubulogenesis. FASEB J 19: 1027 1029.

Scehnet JS, Jiang W, Kumar SR, Krasnoperov V, Trindade A, Benedito R, Djokovic D, Borges C, Ley EJ, Duarte A, et al. 2007. Inhibition of Dll4-mediated signalling induces proliferation of immature vessels and results in poor tissue perfusion. Blood 109: 4753-4760.

Shalaby F, Rossant J, Yamaguchi TP, Gertsenstein M, Wu XF, Breitman ML, Schuh AC. 1995. Failure of blood-island formation and vasculogenesis in Flk-1-deficient mice. Nature 376: 62-66.
Shawber C, Boulter J, Lindsell CE, Weinmaster G. 1996. Jagged2: A serrate-like gene expressed during rat embryogenesis. Dev Biol 180: 370-376.

Shutter JR, Scully S, Fan W, Richards WG, Kitajewski J, Deblandre GA, Kintner CR, Stark KL. 2000. Dll4, a novel Notch ligand expressed in arterial endothelium. Genes Dev 14: 1313-1318.

Siekmann AF, Lawson ND. 2007. Notch signalling limits angiogenic cell behaviour in developing zebrafish arteries. Nature 445: 781-784.

Smith LE, Wesolowski E, McLellan A, Kostyk SK, D'Amato R, Sullivan R, D'Amore PA. 1994. Oxygen-induced retinopathy in the mouse. Invest Ophthalmol Vis Sci 35: $101-111$.

Soker S, Takashima S, Miao HQ, Neufeld G, Klagsbrun M. 1998. Neuropilin-1 is expressed by endothelial and tumor cells as an isoform-specific receptor for vascular endothelial growth factor. Cell 92: 735-745.

Sorensen I, Adams RH, Gossler A. 2009. DLL1-mediated Notch activation regulates endothelial identity in mouse fetal arteries. Blood 113: 5680-5688.

Stone J, Itin A, Alon T, Pe'er J, Gnessin H, Chan-Ling T, Keshet E. 1995. Development of retinal vasculature is mediated by hypoxia-induced vascular endothelial growth factor (VEGF) expression by neuroglia. J Neurosci 15: $4738-4747$.

Suchting S, Freitas C, le Noble F, Benedito R, Breant C, Duarte A, Eichmann A. 2007. The Notch ligand Deltalike 4 negatively regulates endothelial tip cell formation and vessel branching. Proc Natl Acad Sci 104: 3225-3230.

Takahashi H, Shibuya M. 2005. The vascular endothelial growth factor (VEGF)/VEGF receptor system and its role under physiological and pathological conditions. Clin Sci (Lond) 109: 227-241.

Takeshita K, Satoh M, Ii M, Silver M, Limbourg FP, Mukai Y, Rikitake Y, Radtke F, Gridley T, Losordo DW, et al. 2007. Critical role of endothelial Notch1 signalling in postnatal angiogenesis. Circ Res 100: 70-78.

Tammela T, Zarkada G, Wallgard E, Murtomaki A, Suchting S, Wirzenius M, Waltari M, Hellstrom M, Schomber T, Peltonen R, et al. 2008. Blocking VEGFR-3 suppresses angiogenic sprouting and vascular network formation. Nature 454: 656-660.

Tanaka K, Yamaguchi S, Sawano A, Shibuya M. 1997. Characterization of the extracellular domain in vascular endothelial growth factor receptor-1 (Flt-1 tyrosine kinase). Jpn J Cancer Res 88: 867-876.

Thurston G, Kitajewski J. 2008. VEGF and Delta-Notch: Interacting signalling pathways in tumour angiogenesis. Br J Cancer 99: 1204-1209.

Tischer E, Mitchell R, Hartman T, Silva M, Gospodarowicz D, Fiddes JC, Abraham JA. 1991. The human gene for vascular endothelial growth factor. Multiple protein forms are encoded through alternative exon splicing. J Biol Chem 266: 11947-11954.

Uyttendaele H, Marazzi G, Wu G, Yan Q, Sassoon D, Kitajewski J. 1996. Notch4/int-3, a mammary protooncogene, is an endothelial cell-specific mammalian Notch gene. Development 122: 2251-2259.

Uyttendaele H, Ho J, Rossant J, Kitajewski J. 2001. Vascular patterning defects associated with expression of activated 
VEGF and Notch in Tip and Stalk Cell Selection

Notch4 in embryonic endothelium. Proc Natl Acad Sci 98: $5643-5648$.

Weinmaster G. 1998. Notch signalling: Direct or what? Curr Opin Genet Dev 8: 436-442.

Weinmaster G, Roberts VJ, Lemke G. 1992. Notch2: A second mammalian Notch gene. Development 116: 931-941.

Williams CK, Li JL, Murga M, Harris AL, Tosato G. 2006. Up-regulation of the Notch ligand Delta-like 4 inhibits VEGF-induced endothelial cell function. Blood 107: 931-939.
Xue Y, Gao X, Lindsell CE, Norton CR, Chang B, Hicks C, Gendron-Maguire M, Rand EB, Weinmaster G, Gridley T. 1999. Embryonic lethality and vascular defects in mice lacking the Notch ligand Jagged1. Hum Mol Genet 8: 723-730.

Zeng Q, Li S, Chepeha DB, Giordano TJ, Li J, Zhang H, Polverini PJ, Nor J, Kitajewski J, Wang CY. 2005. Crosstalk between tumor and endothelial cells promotes tumor angiogenesis by MAPK activation of Notch signalling. Cancer Cell 8: 13-23. 


\section{$\&_{\mathrm{CSH}}^{\infty} \&$ Cold Spring Harbor

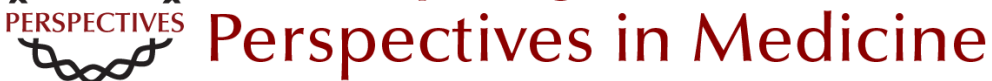

\section{VEGF and Notch in Tip and Stalk Cell Selection}

Raquel Blanco and Holger Gerhardt

Cold Spring Harb Perspect Med 2013; doi: 10.1101/cshperspect.a006569 originally published online October 19, 2012

\section{Subject Collection Angiogenesis}

Extracellular Matrix Regulation of Vascular Morphogenesis, Maturation, and Stabilization George E. Davis and Scott S. Kemp

Endothelial Cell-Pericyte Interactions in the Pathogenesis of Cerebral Cavernous Malformations (CCMs) Wang Min and Jenny Huanjiao Zhou

Lymphatic Clearance and Pump Function Jerome W. Breslin

Platelets and (Lymph)angiogenesis Harvey G. Roweth and Elisabeth M. Battinelli

Modeling Brain Vasculature Immune Interactions In Vitro Ruth Lyck, Hideaki Nishihara, Sidar Aydin, et al.

Human Endothelial Colony-Forming Cells Juan M. Melero-Martin

\section{The Beauty and Complexity of Blood Vessel} Patterning

Victoria L. Bautch and Yoh-suke Mukouyama

Endothelialitis, Microischemia, and

Intussusceptive Angiogenesis in COVID-19 Steven J. Mentzer, Maximilian Ackermann and Danny Jonigk
Regulation of the Blood-Brain Barrier in Health and Disease Cara C. Rada, Kanako Yuki, Jie Ding, et al.

Targeting Angiogenesis via Resolution of Inflammation

Abigail G. Kelly and Dipak Panigrahy

Notch Signaling in the Vasculature: Angiogenesis and Angiocrine Functions

Sana S. Hasan and Andreas Fischer

Signal Transduction and Gene Regulation in the Endothelium

Michel V. Levesque and Timothy Hla

Buttons and Zippers: Endothelial Junctions in

Lymphatic Vessels

Peter Baluk and Donald M. McDonald

Endothelial Cell Fate Determination: A Top Notch Job in Vascular Decision-Making

L.A. Naiche, Stephanie R. Villa and Jan K. Kitajewski

Leukocyte Trafficking in Lymphatic Vessels Aline Bauer, Hazal Tatliadim and Cornelia Halin

Lymphatic Tissue and Organ Engineering for In Vitro Modeling and In Vivo Regeneration Anna M. Kolarzyk, Gigi Wong and Esak Lee

For additional articles in this collection, see http://perspectivesinmedicine.cshlp.org/cgi/collection/ 